\title{
Faktor-faktor yang Memengaruhi Penerimaan Orangtua Terhadap Pemberian Vaksin Varisela pada Anak Usia di Bawah 12 Tahun
}

\author{
Nicolas, ${ }^{1}$ Mulya Rahma Karyanti ${ }^{2}$ \\ ${ }^{1}$ Program Studi Pendidikan Dokter Fakultas Kedokteran, ${ }^{2}$ Departemen Ilmu Kesehatan Anak Fakultas Kedokteran, Universitas Indonesia
}

Latar belakang. Varisela merupakan penyakit dengan tingkat penularan tinggi yang dapat dicegah dengan vaksinasi.

Tujuan. Mengevaluasi penerimaan orangtua terhadap vaksinasi varisela bagi anak berusia di bawah 12 tahun.

Metode. Sampel penelitian merupakan orangtua yang dipilih secara consecutive sampling. Uji yang digunakan adalah metode uji chi-square.

Hasil. Dari 113 responden, 12 (10,6\%) menolak pemberian vaksinasi varisela bagi anak mereka. Terdapat 47\% responden yang memiliki pengetahuan kurang, 22,1\% memiliki sikap kurang, dan 4,4\% memiliki perilaku kurang terhadap varisela. Terdapat pula 5,3\% responden yang memiliki sikap kurang terhadap vaksinasi. Didapatkan hubungan yang signifikan antara sikap orangtua terhadap vaksinasi dengan penerimaan orangtua terhadap vaksinasi varisela $(\mathrm{p}=0,000)$. Tidak terdapat hubungan yang signifikan antara usia $(\mathrm{p}=0,108)$, $p$ endidikan $(\mathrm{p}=0,627)$, pekerjaan $(\mathrm{p}=0,138)$, penghasilan $(\mathrm{p}=0,479)$, pengetahuan $(\mathrm{p}=0,820)$, sikap $(\mathrm{p}=0,460)$, dan perilaku terhadap varisela $(\mathrm{p}=0,087)$ dengan penerimaan vaksinasi varisela.

Kesimpulan. Sikap orangtua terhadap vaksinasi memiliki hubungan yang bermakna dengan penerimaan vaksinasi varisela. Sari Pediatri 2022;23(5):330-5

Kata kunci: cacar air, vaksinasi, varisela

\section{Factors Affecting Varicella Vaccination Acceptance in Parents of Children under 12 Years Old}

Nicolas, ${ }^{1}$ Mulya Rahma Karyanti ${ }^{2}$

Background. Varicella is a highly contagious disease that could be prevented by vaccination. This study aims to evaluate the parents' acceptance of vaccination for their children under 12 years old in Indonesia, which there's no similar study performed before.

Objective. This study aims to evaluate the parents' acceptance of vaccination for their children under 12 years old in Indonesia.

Methods. The samples of this study were parents who were chosen by consecutive sampling. The method used in this study to analyze the data was Chi-square test.

Result. Of the 113 respondents, $12(10,6 \%)$ rejected varicella vaccination for their children. There were $47 \%$ respondents with poor knowledge, $22,1 \%$ with poor attitude, and 4,4\% with poor practice toward varicella. There were also 5,3\% respondents with poor attitude toward vaccination. There was a significant correlation between parental attitude toward vaccination with varicella vaccination acceptance $(\mathrm{p}=0,000)$. There was no significant correlation between parental age $(\mathrm{p}=0,108)$, education $(\mathrm{p}=0,627)$, occupation $(\mathrm{p}=0,138)$, income $(\mathrm{p}=0,479)$, knowledge $(\mathrm{p}=0,820)$, attitude $(\mathrm{p}=0,460)$, and practice $(\mathrm{p}=0,087)$ toward varicella with varicella vaccination acceptance.

Conclusion. Parental attitude toward vaccination have a significant correlation with varicella vaccination acceptance. Sari Pediatri 2022;23(5):330-5

Keywords: acceptance, vaccination, varicella

Alamat korespondensi: Mulya Rahma Karyanti. Departemen Ilmu Kesehatan Anak Fakultas Kedokteran, Universitas Indonesia, Jl. Salemba Raya no.6, Jakarta Pusat, DKI Jakarta, Indonesia. Email: karyanti@ikafkui.net 
$\mathrm{V}$ arisela, penyakit yang sering disebut sebagai cacar air, adalah penyakit yang disebabkan oleh Varicella-Zoster Virus (VZV). ${ }^{1,2}$ Virus Varicella-zoster merupakan virus deoxyribonucleic acid (DNA) dan berada dalam kelompok herpesvirus. ${ }^{1}$ Cacar air dapat menyebar dari seseorang yang sedang terinfeksi melalui sekret sistem respirasinya dan masuk ke dalam traktus respiratorius orang yang sehat. ${ }^{1,2}$ Gejala yang muncul dari orang yang terinfeksi virus Varicella-zoster dapat berupa ruam merah yang didahului dengan demam, anoreksia, dan sakit kepala. ${ }^{1-3}$

Salah satu cara mencegah varisela adalah dengan vaksinasi. Jenis vaksin yang dapat diberikan untuk mencegah varisela ada dua, yaitu vaksin monovalen varisela dan vaksin kombinasi berupa vaksin Measles, Mumps, Rubella, and Varicella (MMRV). ${ }^{1,3}$ Vaksin varisela baiknya diberikan minimal empat minggu setelah pemberian vaksin Measles, Mumps, and Rubella (MMR) atau bersamaan dengan MMR, tetapi injeksi dilakukan pada lokasi yang berbeda dengan MMR. ${ }^{2}$

Belum ada studi mengenai penerimaan masyarakat terhadap pemberian vaksinasi varisela. Penelitian ini akan menilai penerimaan orangtua terhadap pemberian vaksinasi varisela pada anak usia di bawah 12 tahun.

\section{Metode}

Studi potong lintang ini dilaksanakan di Rumah Sakit Umum Pusat Nasional (RSUPN) dr. Cipto Mangunkusumo dan Tempat Pengembangan Anak Makara (TPAM) Universitas Indonesia (UI) pada bulan November 2020. Sampel merupakan data primer yang diambil dari hasil pengisian kuesioner oleh orangtua yang berada di RSUPN dr. Cipto Mangunkusumo dan TPAM UI saat pengambilan data dilaksanakan. Data yang tidak lengkap dan data duplikasi dieksklusikan. Data yang diambil berupa data diri orangtua, pengetahuan orangtua mengenai varisela, sikap orangtua terhadap penyakit varicsela, perilaku orangtua terhadap penyakit varisela, sikap orangtua terhadap vaksinasi, harapan orangtua terhadap vaksinasi varisela, dan penerimaan orangtua terhadap vaksinasi varisela. Besar sampel minimum untuk penelitian ini yang dihitung menggunakan perhitungan besar sampel tunggal adalah 108 sampel. Pada penelitian ini didapatkan 113 sampel yang diambil dengan metode consecutive sampling.

Instrumen kuesioner yang digunakan diuji validitas dan realibilitasnya. Uji validitas dilakukan dengan metode face validity dan uji realibilitas dilakukan dengan menggunakan Kuder-Richardson Formula 20 yang dihitung dengan menggunakan perangkat lunak SPSS v25.

Variabel yang diteliti adalah usia, pendidikan, pekerjaan, penghasilan, pengetahuan mengenai varisela, sikap terhadap penyakit varisela, perilaku terhadap penyakit varisela, sikap terhadap vaksinasi, dan penerimaan terhadap vaksinasi varisela. Usia orangtua berdasarkan atas usia sesuai Kartu Tanda Penduduk (KTP). Pendidikan orangtua dibagi menjadi lulus Sekolah Menengah Atas) SMA dan belum lulus SMA. Pekerjaan orangtua dibagi menjadi orangtua yang bekerja dan orangtua yang tidak bekerja. Penghasilan orangtua dibagi menjadi orangtua dengan penghasilan di bawah Upah Minimum Regional (UMR) Provinsi DKI Jakarta pada tahun 2020 dan penghasilan lebih dari atau sama dengan UMR DKI Jakarta pada tahun 2020. Pengetahuan mengenai varisela, sikap terhadap penyakit varisela, perilaku terhadap penyakit varisela, dan sikap terhadap vaksinasi dibagi menjadi kurang dan baik. Definisi kurang adalah sebagai skor kurang dari $70 \%$ dan baik bila skor lebih dari sama dengan 70\%. Penerimaan vaksinasi varisela dibagi menjadi setuju dan tidak setuju terhadap pemberian vaksinasi varisela bagi anak mereka.

Analisis bivariat dilakukan untuk mengidentifikasi hubungan antara usia, pendidikan, pekerjaan, penghasilan, pengetahuan mengenai varisela, sikap terhadap penyakit varisela, perilaku terhadap penyakit varisela, dan sikap terhadap vaksinasi dengan penerimaan terhadap vaksinasi varisela. Analisis dilakukan menggunakan perangkat lunak SPSS v25 dengan metode uji chi-square. Syarat pengujian data adalah expected value $<5$ berjumlah di bawah $20 \%$. Jika kriteria tersebut tidak terpenuhi, digunakan uji alternatif, yaitu uji Fisher.

\section{Hasil}

Penelitian ini menggunakan data hasil kuesioner dari 118 subjek. Pengambilan data dilakukan di RSUPN Cipto Mangunkusumo dan TPAM UI dalam periode November 2020. Didapatkan 64 subjek dari RSUPN 
Dr. Cipto Mangunkusumo dan 54 subjek dari TPAM UI. Terdapat 1 subjek yang tidak memenuhi kriteria inklusi, 2 subjek yang tidak mengisi data dengan lengkap, serta 2 data duplikasi sehingga didapatkan jumlah data yang dapat diolah adalah $113 \mathrm{ibu}$ dengan anak berusia di bawah 12 tahun.

Penelitian ini juga menyajikan data pandangan subjek terhadap vaksinasi varisela berupa harapan, ketakutan terhadap efek samping, dan biaya tertinggi yang dapat dikeluarkan oleh subjek. Proporsi dari ketiga hal tersebut tertera pada Gambar 1, 2, dan 3.

Tabel 1. Karakteristik dasar sampel penelitian

\begin{tabular}{lc}
\hline & Jumlah (\%) \\
\hline Total & $113(100)$ \\
Usia orangtua (tahun) & \\
$\quad<30$ & $53(46,9)$ \\
$\geq 30$ & $60(53,1)$ \\
Agama orangtua & \\
$\quad$ Islam & $107(95,5)$ \\
Protestan & $3(2,7)$ \\
Katolik & $1(0,9)$ \\
Buddha & $1(0,9)$ \\
Konghucu & $0(0)$ \\
Pendidikan terakhir & \\
Belum lulus SMA & $13(11,5)$ \\
Lulus SMA & $100(88,5)$ \\
Pekerjaan & \\
Tidak bekerja & $62(54,9)$ \\
Bekerja & $51(45,1)$ \\
Penghasilan & \\
Kurang dari UMR & $62(48,7)$ \\
Lebih atau sama dengan UMR & $51(51,3)$ \\
Penerimaan vaksinasi varisela & \\
Tidak setuju & $12(10,6)$ \\
Setuju & $101(89,4)$ \\
\hline
\end{tabular}

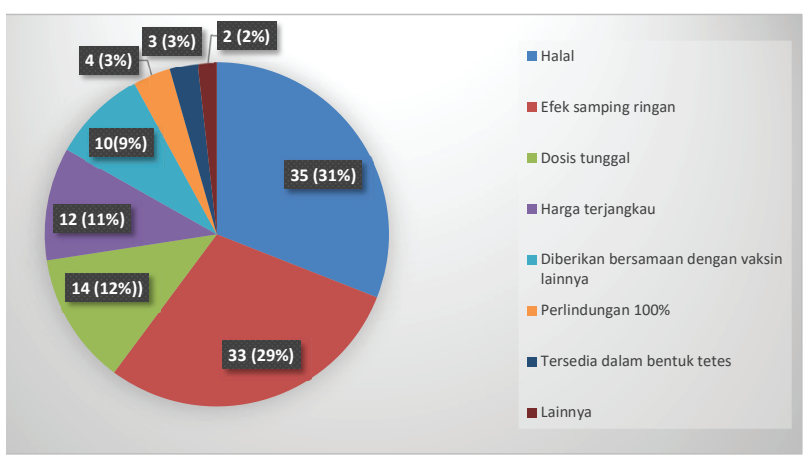

Gambar 1. Harapan orangtua terhadap vaksinasi varisela dari 113 responden

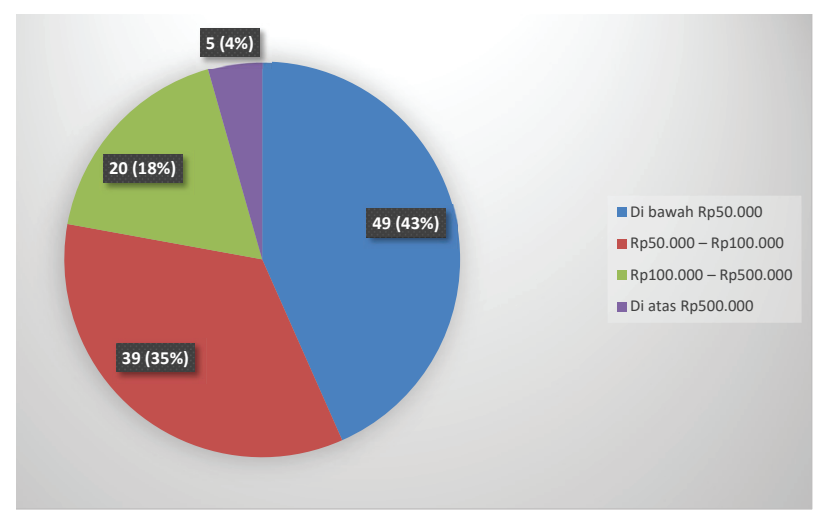

Gambar 2. Efek samping yang paling ditakutkan orangtua dari vaksinasi varisela dari 113 responden

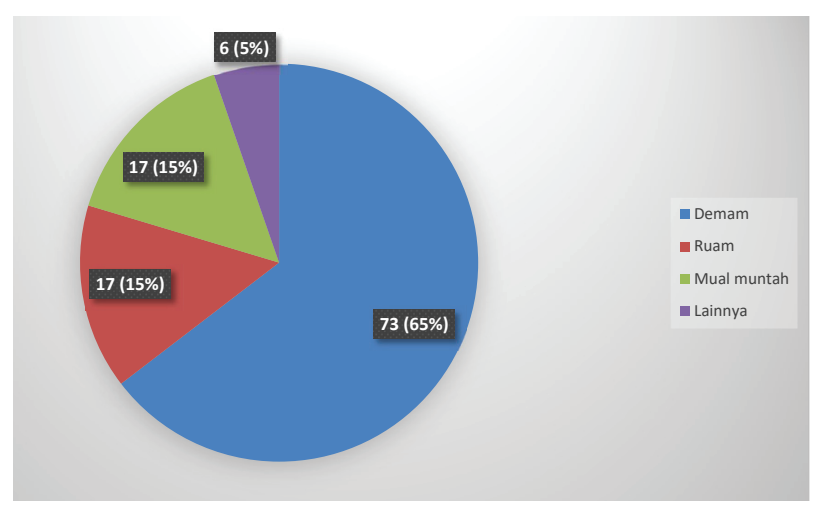

Gambar 3. Efek samping yang paling ditakutkan orangtua dari vaksinasi varisela dari 113

\section{Pembahasan}

Pengetahuan $(47 \%)$, sikap $(22,1 \%)$, dan perilaku orangtua yang kurang $(4,4 \%)$ terhadap varisela, serta sikap yang kurang $(5,3 \%)$ terhadap vaksinasi membutuhkan perhatian khusus. Edukasi mengenai penyebaran virus varisela, kerentanan seseorang terhadap varisela, serta mengenai vaksinasi itu sendiri penting diberikan bagi orangtua.

Menurut ulasan Ames dkk, ${ }^{4}$ tenaga kesehatan merupakan sumber informasi penting dan dipercaya orangtua untuk mendapatkan informasi vaksinasi. Orangtua mengharapkan adanya informasi vaksinasi di luar sarana kesehatan. Hal lain yang penting bagi orangtua adalah informasi jadwal pelaksanaan vaksinasi. Orangtua juga mengalami hambatan dalam penerimaan informasi mengenai varisela, yaitu sulitnya menentukan sumber informasi yang dapat dipercaya. Selain itu, komunikasi yang buruk oleh tenaga kesehatan juga dapat memengaruhi keputusan orangtua dalam menjalankan imunisasi. ${ }^{4}$ 
Pemberian informasi vaksinasi baiknya diberikan oleh tenaga kesehatan. Penyebaran informasi dapat dilakukan melalui media sosial maupun secara langsung. Pemberian informasi vaksinasi juga baiknya di saat yang tepat, yaitu beberapa saat sebelum jadwal vaksinasi, seperti pada jadwal vaksinasi sebelumnya.

Pada penelitian kami, tidak didapatkan hubungan antara usia orangtua dengan penerimaan vaksinasi varisela. Serupa dengan penelitian Putri ${ }^{5}$ yang melaporkan hasil tidak terdapat hubungan antara usia orangtua dengan kepatuhan pemberian imunisasi dasar. Analisis data pada studi tersebut merupakan analisis bivariat dengan metode uji chi-square. Pada studi di Italia, Vezzosi dkk, ${ }^{6}$ juga didapatkan hasil serupa Studi tersebut dilaksanakan pada 4 lokasi dengan metode pengambilan sampel berupa random sampling. Berdasarkan hasil studi terdahulu tersebut memperkuat bukti bahwa tidak ada hubungan antara usia orangtua dengan penerimaan vaksinasi varisela.

Penelitian kami juga tidak mendapatkan hubungan antara pendidikan terakhir orangtua dengan penerimaan vaksinasi variselsa. Sementara studi Putri ${ }^{5}$ mendapatkan hubungan antara tingkat pendidikan ibu dengan penerimaan imunisasi dasar. Studi ini dilaksanakan di satu lokasi saja dan analisis dilakukan dengan metode uji chi-square.

Menurut ulasan Bocquier dkk, ${ }^{7}$ terdapat kontroversi antara orangtua dengan pendidikan yang tinggi terhadap penerimaan vaksinasi. Vaksinasi yang diinklusi dalam studi ini, di antaranya adalah MMR, rotavirus, dan varisela. Studi yang dilakukan oleh Vezzosi $\mathrm{dkk}^{6}$ menunjukkan hubungan antara tingkat pendidikan orangtua dengan penerimaan vaksinasi varisela.

Hasil penelitian kami didukung oleh studi Vezzosi $\mathrm{dkk}$, tetapi masih terdapat hasil yang beragam pada beberapa studi yang diulas oleh Bocquier dkk. Hasil berbeda juga didapat pada studi Putri. Oleh karena itu, masih dibutuhkan penelitian lebih lanjut.

Penelitian kami tidak mendapatkan hubungan antara pekerjaan orangtua dengan penerimaan vaksinasi varisela. Lucyk $\mathrm{dkk}^{8}{ }^{8}$ melaporkan hubungan antara pekerjaan orangtua dengan penerimaan vaksinasi influenza. Kelompok orangtua pada studi ini dibagi menjadi orangtua yang bekerja sebagai seorang profesional dan yang tidak mempunyai pekerjaan tetap atau bahkan tidak bekerja. Hasil analisis penelitian kami didukung ulasan yang dibuat Lucyk dkk, tetapi jenis vaksinasi yang terdapat pada ulasan tersebut bukan vaksinasi varisela. Masih dibutuhkan penelitian lebih lanjut untuk mengetahui hubungan pekerjaan orangtua dengan penerimaan vaksinasi varisela.

Penelitian kami tidak mendapatkan hubungan antara penghasilan orangtua dengan penerimaan vaksinasi. Pada ulasan yang dibuat oleh Lucyk dkk, ${ }^{8} 3$ studi menunjukkan terdapat hubungan antara penghasilan orangtua dengan penerimaan vaksinasi. Vaksinasi yang dimaksud pada studi ini adalah vaksinasi H1N1 dan influenza. Ulasan yang dibuat oleh Bocquier ${ }^{7}$ menunjukkan tidak didapatkan hubungan antara penghasilan orangtua dengan vaksinasi MMR. Pada studi tersebut dilakukan analisis multivariat.

Hasil penelitian kami didukung oleh studi Bocquier. Namun begitu, hasil berbeda didapatkan pada tiga studi lainnya. Tidak terdapat studi mengenai varisela di antara keempat studi tersebut. Masih dibutuhkan penelitian lebih lanjut untuk mengetahui hubungan antara penghasilan orangtua dengan penerimaan vaksinasi varisela.

Penelitian kami tidak mendapatkan hubungan antara pengetahuan orangtua mengenai varisela dengan penerimaan vaksinasi varisela. Namun, Malik, ${ }^{9}$ melaporkan hubungan antara pengetahuan dengan penerimaan vaksinasi. Subjek pada studi tersebut berjumlah 81 sampel ibu yang memiliki anak berusia 9-72 bulan dan berada di Kelurahan Tompo Balang Kecamatan Somba Opu Kabupaten Gowa. Jenis vaksinasi yang dipilih dalam penelitian tersebut adalah vaksin Measles Rubella (MR). ${ }^{9}$

Menurut ulasan oleh Smith $\mathrm{dkk}^{10}$ yang mencakup 6 penelitian, terdapat hubungan antara pengetahuan orangtua dengan penerimaan vaksinasi. Selain itu, terdapat pula 6 penelitian lainnya yang menunjukkan hubungan antara pengetahuan dengan penolakan terhadap vaksinasi. Terdapat 2 studi yang menunjukkan hubungan baik antara pengetahuan orangtua mengenai pentingnya vaksinasi dengan penerimaan vaksinasi. Pada studi oleh Smith dkk tersebut, vaksinasi yang dimaksud tidaklah hanya mengenai varisela, tetapi juga vaksinasi lainnya. Hasil penelitian kami masih berbeda dengan penelitian terdahulu. Perbedaan hasil ini kemungkinan jenis vaksin yang berbeda. Sesuai studi yang dilakukan oleh Gualano dkk, ${ }^{11}$ jenis vaksinasi yang berbeda akan memengaruhi penerimaan vaksinasinya. Penelitian kami tidak mendapatkan hubungan antara sikap orangtua terhadap varisela dengan penerimaan vaksinasi varisela.

Menurut ulasan oleh Schmid dkk, ${ }^{12}$ sikap buruk memiliki hubungan yang kuat terhadap penolakan vaksinasi influenza. Menurut ulasan oleh Özdemir dkk, ${ }^{13}$ 
terdapat 3 studi yang menunjukkan bahwa sikap buruk juga akan menurunkan penerimaan vaksinasi HPV. Menurut studi Putri ${ }^{5}$ ditemukan hubungan antara sikap ibu dengan penerimaan imunisasi dasar. Studi tersebut memiliki jumlah sampel 98 ibu yang memiliki balita dan berada di Dukuh Pilangbangau. Penelitian ini merupakan penelitian multicenter, sedangkan pada studi yang dilakukan oleh Putri dilakukan pada satu lokasi saja. Studi oleh Putri dan ulasan oleh Schmid pun tidak membahas mengenai vaksinasi varisela. Perbedaan hasil ini kemungkinan disebabkan oleh perbedaan jenis vaksinasi dan lokasi pengambilan sampel yang multicenter. Sikap orangtua yang kurang terhadap varisela $(22,1 \%)$ juga membutuhkan perhatian khusus.

Penelitian kami tidak mendapatkan hubungan antara perilaku orangtua terhadap varisela dengan penerimaan vaksinasi varisela. Pada ulasan oleh Smith $\mathrm{dkk},{ }^{10}$ hanya terdapat satu studi yang menunjukkan hubungan antara perilaku orangtua dengan penerimaan vaksinasi pada anak. Tiga studi lainnya menunjukkan tidak ada hubungan antara keduanya. Jenis vaksinasi yang diinklusi pada ulasan tersebut tidak hanya varisela. Vezzosi $\mathrm{dkk}^{6}$ melaporkan bahwa terdapat hubungan antara perilaku orangtua terhadap varisela dengan penerimaan vaksinasi varisela. Studi tersebut dilaksanakan di 4 sekolah dengan cara random sampling. Hasil dari penelitian kami berbeda dengan Vezzosi dkk. Kemungkinan perbedaan hasil ini disebabkan oleh jumlah sampel studi Vezzosi dkk yang lebih banyak dibandingkan dengan penelitian kami. Jumlah sampel yang lebih banyak dapat meningkatkan signifikansi dari suatu penelitian.

Penelitian kami mendapatkan hubungan antara sikap orangtua terhadap vaksinasi dengan penerimaan vaksinasi varisela. Menurut ulasan oleh Smith $\mathrm{dkk},{ }^{10}$ terdapat 11 studi yang menunjukkan hubungan baik antara persepsi orangtua mengenai pentingnya vaksinasi dengan penerimaan vaksinasi. Vaksinasi yang dimaksudkan menginklusi banyak jenis vaksin, di antaranya adalah vaksin MMR. Dua studi memiliki kualitas yang baik dan satu studi memiliki kualitas yang buruk. Pada studi Vezzosi dkk, ${ }^{6}$ didapatkan hubungan antara sikap orangtua terhadap vaksinasi dengan penerimaan vaksinasi varisela. Studi ini merupakan studi potong lintang dengan 414 sampel dan bersifat multicenter. Analisis multivariat dilakukan pada studi ini. Hasil penelitian kami diperkuat oleh studi dan ulasan yang telah ada bahwa terdapat hubungan antara sikap orangtua terhadap vaksinasi dengan penerimaan vaksinasi varisela.
Penelitian kami dilakukan secara multicenter sehingga dapat mewakili persebaran sampel dengan domisili yang luas. Sampel pada penelitian ini juga diharapkan dapat mewakili populasi Indonesia. Penelitian mengenai penerimaan vaksinasi varisela di Indonesia belum pernah dilakukan sebelumnya sehingga penelitian ini dapat menjadi acuan bagi peneliti lain yang akan melaksanakan penelitian dengan tema serupa. Sampel pada penelitian hanya diambil pada 2 lokasi, yaitu Depok dan Jakarta. Pengambilan data lebih baik dilakukan di lokasi yang lebih banyak supaya dapat mewakili populasi Indonesia dengan lebih baik.

\section{Kesimpulan}

Pengetahuan, sikap, dan perilaku terhadap varisela, serta sikap kurang terhadap vaksinasi banyak ditemukan. Pengetahuan orangtua ditemukan kurang perihal ketahanan virus varisela di luar pejamu, infeksi ulang pada orang yang sudah mengalami varisela sebelumnya, mortalitas penyakit, dan penularannya. Harapan orangtua terbanyak terhadap vaksinasi varisela adalah tidak ada efek samping demam, berharga di bawah Rp50.000, dan halal. Usia, pendidikan, pekerjaan, dan penghasilan orangtua tidak berhubungan dengan penerimaan orangtua terhadap vaksinasi varisela. Pengetahuan, sikap, dan perilaku orangtua terhadap penyakit varisela tidak berhubungan dengan penerimaan orangtua terhadap vaksinasi varisela. Sementara sikap orangtua terhadap vaksinasi memiliki hubungan dengan penerimaan orangtua terhadap vaksinasi varisela.

\section{Daftar pustaka}

1. Weinbaum C. Varicella. Atlanta: Centers for Disease Control and Prevention; 2019.

2. Kliegman RM, Geme JW, Blum NJ, Shah SS, Tasker RC, Wilson KM. Varicella-zoster virus. Dalam: Nelson textbook of pedriatics. Edisi 21. Amsterdam: Elsevier; 2019.h. 6866-88.

3. Centers for Disease Control and Prevention. Varicella (chickenpox) vaccine: what you need to know. Saint Paul: Immunization Action Coalition. 2018. Diakses Desember 2020. Didapat dari: https://www.immunize.org/vis/indonesian_ varicella.pdf.

4. Ames H, Glenton C, Lewin S. Parents' and informal caregivers' views and experiences of communication about routine childhood vaccination: a synthesis of qualitative evidence. Cochrane Database Syst Rev 2017;2:1-30. 
5. Putri RS. Faktor-faktor yang mempengaruhi kepatuhan ibu dalam pemberian imunisasi dasar pada balita di dukuh pilangbangau desa sepat masaran sragen tahun 2016. Jurnal Ilmiah Keperawatan 2016;5:1-93.

6. Vezzosi L, Santagati G, Angelillo IF. Knowledge, attitudes, and behaviors of parents towards varicella and its vaccination. BMC Infect Dis 2017;17:172-80.

7. Bocquier A, Ward J, Raude J, Peretti-Watel P, Verger P. Socioeconomic differences in childhood vaccination in developed countries: a systematic review of quantitative studies. Expert Rev Vaccines 2017;2:1-23.

8. Lucyk K, Simmonds KA, Lorenzetti DL, Drews SJ, Svenson LW, Russell ML. The association between influenza vaccination and socioeconomic status in high income countries varies by the measure used: a systematic review. BMC Med Res Methodol 2019;19:1-23.

9. Malik M. Faktor-faktor yang mempengaruhi penerimaan ibu terhadap pemberian imunisasi MR (measles rubella) di kelurahan tompo balang kecamatan somba opu kabupaten gowa tahun 2019. Jurnal Bidan Komunitas. 2019;4:1-86.

10. Smith LE, Amlôt R, Weinman J, Yiend J, Rubin GJ. A systematic review of factors affecting vaccine uptake in young children. Vaccine 2017;35:6059-69.

11. Gualano M, Olivero E, Voglino G, Corezzi M, Rossello P, Vicentini C, dkk. Knowledge, attitudes and beliefs towards compulsory vaccination: a systematic review. Hum Vaccin Immunother 2019;15:918-31.

12. Schmid P, Rauber D, Betsch C, Lidolt G, Denker M-L. Barriers of Influenza Vaccination Intention and Behavior - A Systematic Review of Influenza Vaccine Hesitancy, 20052016. PLoS One 2016;12:1-46.

13. Özdemir S, Akkaya R, Karașahin KE. Analysis of communitybased studies related with knowledge, awareness, attitude, and behaviors towards HPV and HPV vaccine published in Turkey: A systematic review. J Turk Ger Gynecol Assoc 2020;21:111-23. 